\title{
DIATOMS OF THE GENUS GOMPHONEMA EHR. (BACILLARIOPHYCEAE) FROM A KARSTIC STREAM IN THE KRAKOWSKO-CZESTOCHOWSKA UPLAND
}

\author{
AgAta Wojtal \\ Department of Phycology, W. Szafer Institute of Botany \\ Polish Academy of Sciences \\ Lubicz 46, 31-512 Cracow, Poland \\ e-mail: wojtal@ib-pan.krakow.pl \\ (Received: May 17, 2002. Accepted: June 6, 2003)
}

\begin{abstract}
This paper presents the results of a floristic study focusing on taxa representing the genus Gomphonema in Kobylanka stream, situated ca $30 \mathrm{~km} \mathrm{NW}$ of Kraków. Species belonging to the genus Gomphonema Ehr. were very frequently observed diatom taxa in the material studied. Amongst 272 diatom taxa recorded in the studied material, 13 belong to this genus. Some of them are widespread and often found in Poland; others such as Gomphonema micropus Kütz. and G. sarcophagus Greg. are rarely or for the first time reported from the Kraków-Częstochowa Upland. G. brebissonii Reichardt, G. lagerheimii A. Cl. and G. parallelistriatum Lange-Bert. and Reichardt are new to the Polish flora.

Identification of the diatom flora was based on light (LM) and scanning electron microscopy (SEM). Morphological characters and dimensions of frustules were measured for all taxa reported. Ecological requirements, remarks on distribution, and photographic documentation are also given.
\end{abstract}

KEY WORDS: Bacillariophyceae, Gomphonema, taxonomy, stream ecology, Kraków-Częstochowa Upland.

\section{INTRODUCTION}

Diatoms are considered very useful indicators of environmental changes, including acidification, eutrophication and climate change. The autecological characteristics indispensable in such studies are dispersed in the extensive literature. Some of the most important environmental factors in aquatic and wetland ecosystems include moisture conditions, $\mathrm{pH}$, trophic status, salinity, saprobity, organic nitrogen and dissolved oxygen (Van Dam et al. 1994). In relation to autecology, clear correlations with specific ecological conditions have been established for 1000 taxa known from Central Europe so far (Lange-Bertalot 1999). Although some genera are characteristic of a particular environment, more precise environmental indicators can be obtained from the species composition of diatom assemblages. Indicator values are most lacking among the rarer taxa, which usually constitute only a very small percentage of the diatom assemblages. A precise ecological interpretation of the presence or absence of particular diatom species used as bioindicators requires correct identification. This can be an especially difficult task in the case of the genus Gomphonema, because the number of taxa belonging to this genus has more than doubled since 1986 (Lange-Ber- talot 1997). Such a drastic increase in the number of taxa in Gomphonema and in the number of diatom species in general is the result of intensification of diatom studies, including habitats nearly unexplored, and following the description of new taxa (Van Dam et al. 1994). Taxa belonging to Gomphonema cannot be identified solely on the basis of LM studies. Because the characteristics of some species overlap, SEM studies are necessary to differentiate these taxa (Krammer and Lange-Bertalot 2000).

According to Round et al. (1990), taxa belonging to the genus Gomphonema Ehr. are characterised as follows; linear or lanceolate heteropolar valves; wedge-shaped girdle view; uniseriate (occasionally biseriate) striae; pore fields present at the foot pole (through which the mucilage stalks are secreted); straight raphe sternum; straight or slightly sinuous raphe fissures, unequal in length (the upper one is shorter); and usually one to a few stigma.

Species belonging to Gomphonema Ehr. are relatively common in freshwater diatom communities. They often form branched mucilaginous stalks attached to solid substrata. The development of pedunculate forms on the surface transforms the structure of the community from two-dimensional to three-dimensional, probably the most complex form observed in natural conditions (Round et al. 1990). 
The environmental conditions of the karstic stream studied here are suitable for many diatom taxa. This paper presents the results of taxonomic studies of diatom taxa belonging to the genus Gomphonema associated mainly with stones and filamentous thalli of Vaucheria sp., Cladophora sp. and submerged vascular plants. Some of them [e.g., Gomphonema angustatum Ehr., G. olivaceum (Horn.) Bréb. or G. parvulum (Kütz.) Rabh.] are well-known cosmopolitans, while others (e.g. G. brebissonii, G. parallelistriatum) have rarely been recorded in Poland to date or are new to the Polish flora.

\section{STUDY AREA}

The small Kobylanka stream $(7.3 \mathrm{~km}$ long, 0.4-1.2 m wide, 0.1-0.3 m deep) is one of the numerous tributaries of the Rudawa River, flowing through the „Dolinki Krakowskie" Landscape Park.

The limestones of the substratum are still subject to karstic processes, which result in the formation of numerous caves and spring basins. The stream is classified as summer-cold and winter-warm (Wojtal 2001). The most dangerous threats to the natural character of the springs are agricultural areas situated above the Dolina Kobylańska valley.

The upper reach of the stream has preserved its natural character in certain parts (in the Dolina Kobylańska Valley), but beginning from Kobylany village it is strongly affected by anthropogenic factors. The most characteristic features of the stream are karstic springs, bed imbricated with limestone gravel, and some sections flowing underground. During the study period the water temperature was 6.2-9. $0^{\circ} \mathrm{C}$ (rarely higher), the velocity ranged from 10 to 18 $\mathrm{cm} / \mathrm{s}^{-1}$, and conductivity was moderate, generally $360-480$ $\mu \mathrm{S} / \mathrm{cm}^{-1}$. The $\mathrm{pH}$ values usually varied from 6.4 to 7.6 .

\section{MATERIAL AND METHODS}

The material was collected within a period from 1993 to 2002 year. Epilithic samples were scraped from the surface of gravel (of diameter 32-64 mm) and boulders (of diame-

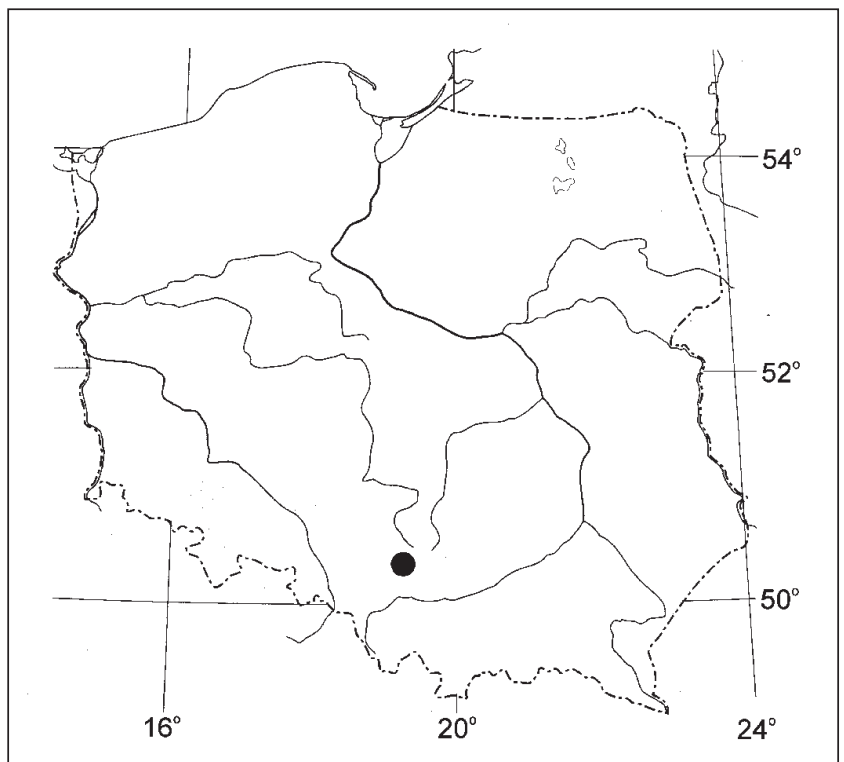

Fig. 1. Location of the study area in Poland. ter $65-130$ and $131-260 \mathrm{~mm}$ ) by meaning of a scalpel blade. Small stones were collected from the sampling sites and transported to the laboratory. Epiphyton was taken from filaments of Vaucheria sp., Cladophora sp. and from submerged stems or leaves of macrophytes. The collected material was transferred into $15 \mathrm{ml}$. plastic scintillation vials and preserved in $4 \%$ formaldehyde. The samples were treated with $\mathrm{HCl}$, washed several times with distilled water, and boiled in concentrated $\mathrm{H}_{2} \mathrm{O}_{2}$ with small amounts of $\mathrm{KClO}_{3}$ in order to remove organic matter. After washing several times with distilled water, the material was airdried on coverglasses and mounted in Naphrax. Observations were performed with a Nikon Optiphot microscope equipped with a Plan $\times 100$ oil immersion lens (numerical aperture 1.25) as well as Nikon FX-35 photomicroscopy unit. SEM observations were made on cleaned material coated with gold by means of a Philips microscope. Species new to the Kraków-Częstochowa Upland are indicated by an asterisk (*); records new to the Polish flora are marked by two asterisks $(* *)$.

The ecological indicator values for the individual taxa reported in this paper were mainly based on the classification by Van Dam et al. (1994).

\section{RESULTS}

\section{Gomphonema acuminatum Ehr. Fig. 2: 1-7.}

Ref. Krammer and Lange-Bertalot 1986 (Fig. 160: 1-12); Reichardt 1999 (Figs 52: 1-14; 53: 1-17). A highly variable taxon characterised by triundulate, strongly heteropolar valves, 34.2-54.4 $\mu \mathrm{m}$ long and 8.0-11.5 $\mu \mathrm{m}$ wide (head-pole), with narrow foot-pole and much wider, cuneate head-pole. The external raphe fissures are slightly sinuous. The striae are radiate, 11-12 in $10 \mu \mathrm{m}$, composed of puncta.

Occurred in the material collected from unpolluted part of the stream, from submerged vascular plants (e.g., Lemna minor L.), upstream of Kobylany village, where the water was eutrophicated by domestic birds. Known from various waterbodies of Kraków-Częstochowa Upland (Gumiński 1947; Siemińska 1947; Skalna 1969, Hojda 1971).

This species is considered as a cosmopolitan, alkaliphilous (Krammer and Lange-Bertalot 1986; Reichardt 1999). It occurs in fresh and brackish waters, tolerating very low concentrations of organically bound nitrogen, requires fairly high oxygen level, b-mesosaprobous, eutraphentic, sometimes recorded from aerophytic habitats (Van Dam et al. 1994).

Gomphonema angustatum (Kütz.) Rabenh. Fig. 2: 8.

Ref. Reichardt 1999 (Figs 23: 1-10; 13-16; 24: 1-37).

Valves linear-lanceolate, 27.0-35.8 $\mu \mathrm{m}$ long and 8-8.8 $\mu \mathrm{m}$ wide, with narrow foot-pole and rostrate head-pole. 27.0 - $35.8 \mathrm{~mm}$ long and 8-8,8 $\mathrm{mm}$ wide. External raphe fissures straight. Transapical striae slightly radiate, 12.013.5 in $10 \mu \mathrm{m}$.

It occurred very rarely in samples collected from filamentous thali of Vaucheria sp. and submerged mosses along the whole stream.

The species was frequently reported from Kraków-Częstochowa Upland (e.g. Skalna 1969; Kubik 1970; Hojda 1971) and others regions of Poland. Cosmopolitan species, which prefers mesotrophic waters with higher electrolyte content (Krammer and Lange-Bertalot 1986). 

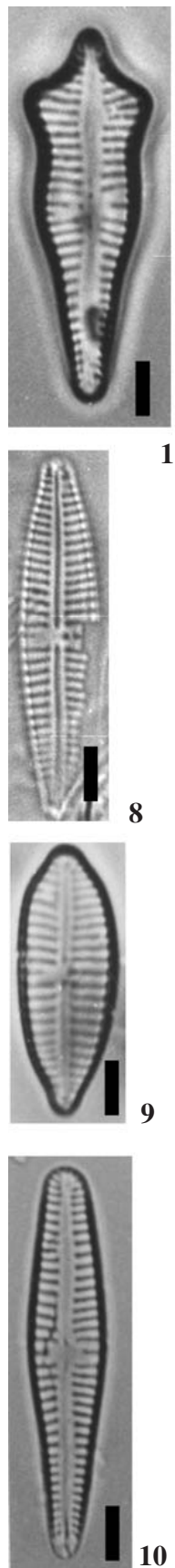

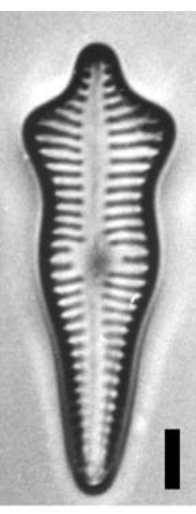

2
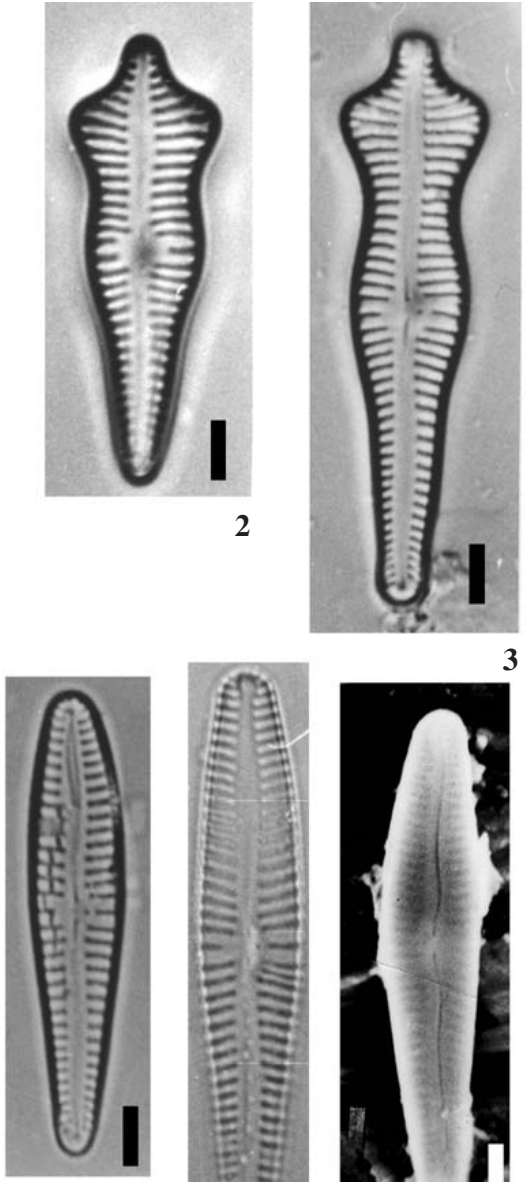

11
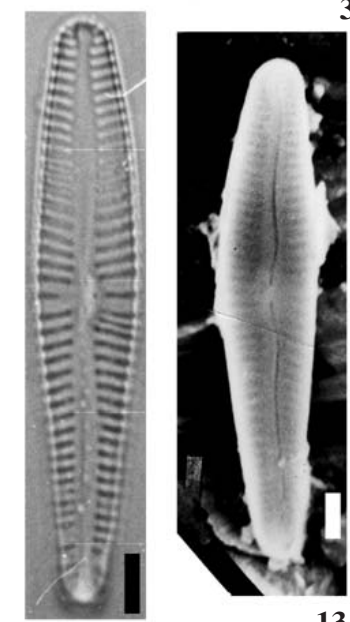

13

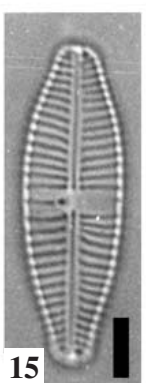

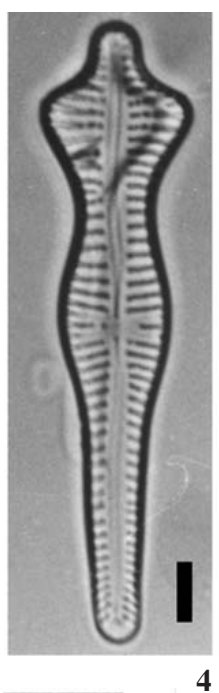
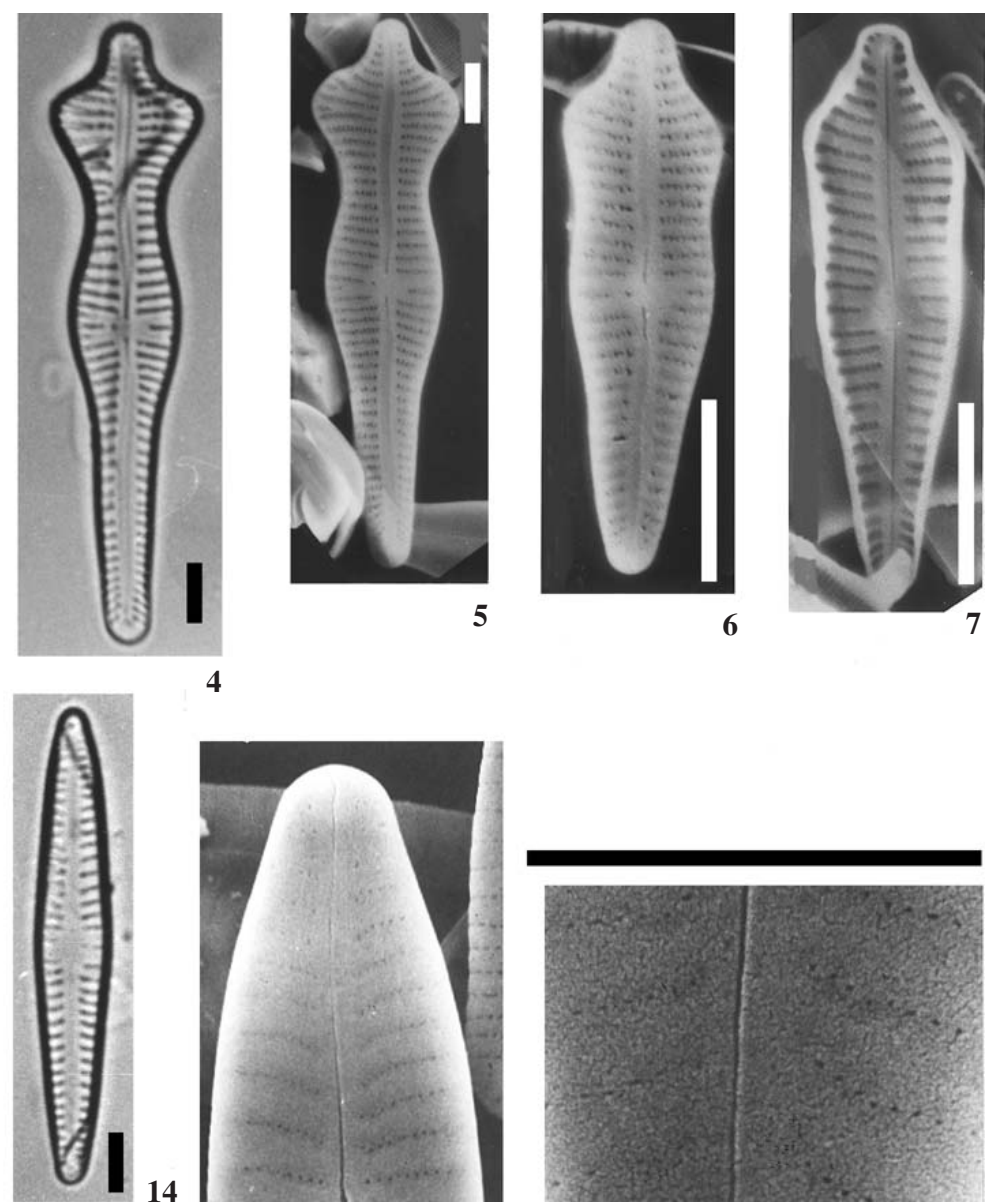

4
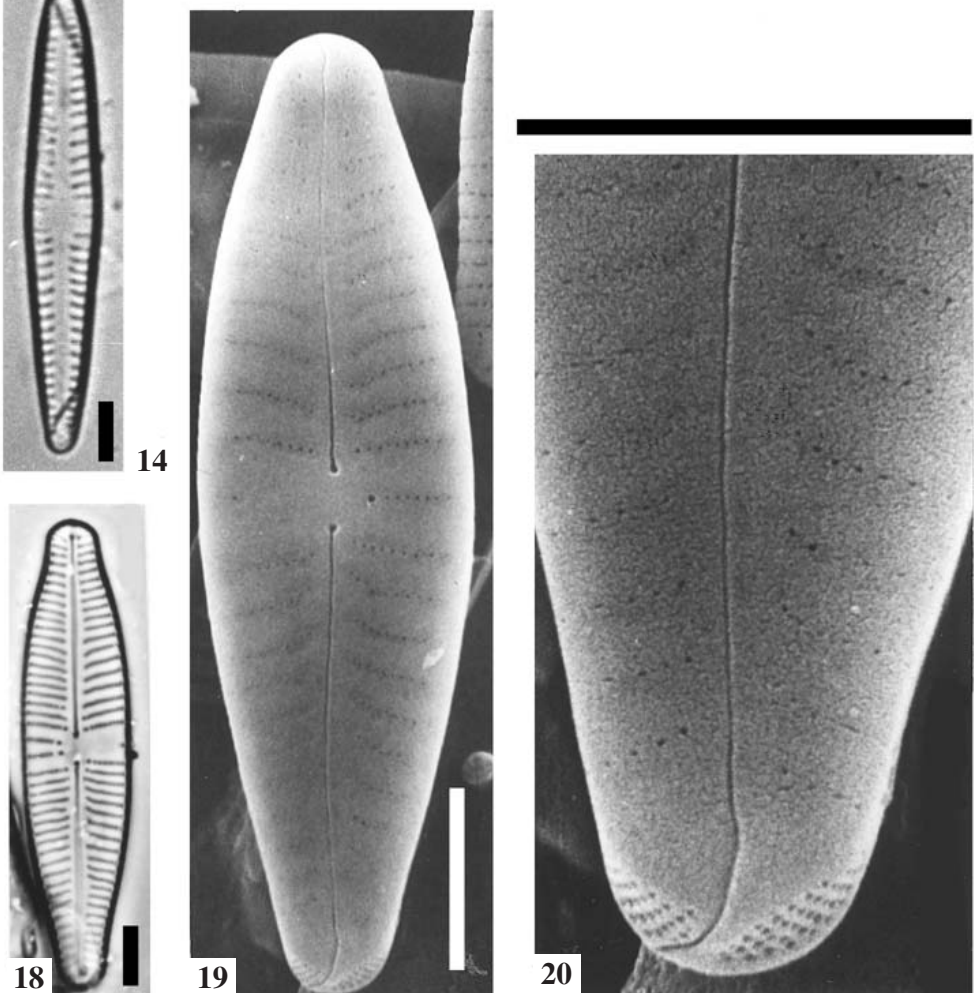

Fig. 2: 1-20: 1-7: Gomphonema acuminatum Ehr., 8: G. angustatum (Kütz.) Rabenh., 9: G. brebissonii Kütz., 10-13: G. clavatum Ehr., 14: G. lagerheimil A. Cl., 15-20: G. micropus Kütz. Scale bars: $5 \mu \mathrm{m}$ (1-5, 8-20); $10 \mu \mathrm{m}$ (6-7). LM photographs: 1-4, 8-12, 14-18. SEM photographs: 5-7, 13, and 19-20.

** Gomphonema brebissonii Kütz. Fig. 2: 9.

Ref. Reichardt 1999 (Fig. 56: 1-14, 57: 1-13).

Valves are strongly heteropolar, with relatively narrow foot-pole and capitate head-pole; 19.4-22.8 $\mu \mathrm{m}$ long and 4.8-5.2 $\mu \mathrm{m}$ wide. Axial area narrow. Transapical striae are slightly radiate in the middle part of valve, becoming radiate towards apices, 12 in $10 \mu \mathrm{m}$.

In the material studied single specimens were observed in epilithic communities collected from larger stones and on Lemna minor L.

It occurs in waters of lower and moderate electrolyte contents, widespread but prefers cold waters and more often reported from northern regions (Reichardt 1999). New to the Polish flora.
Gomphonema clavatum Ehr. Fig. 2: 10-13.

(= Gomphonema longiceps Ehr.; G. longiceps Ehr. var. montanum (Schum.) Cl.; G. longiceps Ehr. var. subclavatum Grun.) Ref. Krammer and Lange-Bertalot 1986 (Fig. 163: 1-12); Reichardt 1999 (Fig. 25: 24-26).

Valves heteropolar, linear-lanceolate 26.2-48.6 $\mu \mathrm{m}$ long and 7.2-8.6 $\mu \mathrm{m}$ wide, with relatively narrow foot-pole and a broader head-pole. Transapical striae are parallel, in the middle part of valve slightly radiate, 7.0-8.5 in $10 \mu \mathrm{m}$.

It was recorded in epiphytic communities on Lemna minor L. and submerged mosses in unpolluted part of the stream.

This species was reported from the Kraków-Częstochowa Upland from Mydlniki ponds (Siemińska 1947), and frequently mentioned from the other parts of Poland by e.g. 
Schumann (1863, 1867), Kozłowski (1890), Mrozińska (1989).

This species belongs to the group of widespread diatom taxa, which occur in oligosaprobic waters with wide range of electrolyte content, in various kind of waterbodies (Krammer and Lange-Bertalot 1986). According to Van Dam et al. (1994) it prefers fresh circumneutral waters with continuously high dissolved oxygen level, oligosaprobous, meso-eutraphentic, tolerant to very low concentrations of organically bound nitrogen, sometimes reported from aerophytic habitats.

** Gomphonema lagerheimii A. Cl. Fig. 2: 14.

Ref. Krammer and Lange-Bertalot 1986 (Fig. 155: 22-24).

The valves are only slightly heteropolar, lanceolate; 36.2 $\mu \mathrm{m}$ long and $6.4 \mu \mathrm{m}$ wide. The transapical striae are radiate, more widely spaced in the middle part of valve, slightly radiate, 8 in $10 \mu \mathrm{m}$.

Only one specimen was recorded in epiphytic communities collected from submerged mosses in unpolluted part of the stream.

This species belongs to the group of rare diatom taxa, which occur in oligosaprobic waters with low electrolyte content (Krammer and Lange-Bertalot 1986). According to Van Dam et al. (1994) it prefers fresh circumneutral, oligosaprobous and oligotrophic waters with continuously high dissolved oxygen level.

Gomphonema micropus Kütz. Fig. 2: 15-20 and Fig. 3: 1-3. (Gomphonema parvulum (Kütz.) Grun. var. micropus (Kütz.) $\mathrm{Cl}$.

Ref. Krammer and Lange-Bertalot 1991 (Fig. 74: 1-14), Lange-Bertalot 1993 (Fig. 73: 1-13) Reichardt 1999 (36: 114; 37: 1-29; 38: 1-15; 39: 15-17, 27-29).

The valves are lanceolate, heteropolar 18.8-47.2 $\mu \mathrm{m}$ long and 6.8-9.2 wide. Striae slightly radiate 8-10 in $10 \mu \mathrm{m}$. Central area pronounced unilateral. Observed specimens shown high variability in size, shape and striae density.

It occurred along the whole stream, but most numerous populations were observed on the surfaces of the stones, where this species dominated.

This species was reported from Kraków-Częstochowa Upland only from springs of Będkówka stream (Kubik 1970), frequently mentioned from the other parts of Poland (e.g. Gutwiński 1893, 1909; Filarszky 1899; Skalska and Kaczmarczyk 1980).

According to Reichardt (1999) it is a widespread taxon occurring mainly in small waterbodies. It belongs to the group of alkaliphilous taxa, occurring in both fresh and brackish water habitats with fairly high oxygen level, tolerating elevated concentrations of organically bound nitrogen, $\beta$-mesosaprobous, eutraphentic, often recorded also from aerophytic habitats (Van Dam et al. 1994).

* Gomphonema minutum (Ag.) Ag. fo. minutum Fig. 3: 4-6. (= Gomphonema tenellum Kütz.)

Ref. Krammer and Lange-Bertalot 1986 (Fig. 159: 5-10).

The valves are club-shaped, with strongly narrowed footpole, 15.6-28.2 $\mu \mathrm{m}$ long and 4.8-7.0 $\mu \mathrm{m}$ wide. Transapical area is narrow, external raphe fissures are slightly sinuous. The transapical striae are radiate in the middle part of the valves becoming parallel to slightly radiate towards the poles, $15.5-18.0$ in $10 \mu \mathrm{m}$. The density of the striae is relat- ed to the quality of inhabited water (Krammer and LangeBertalot 1991).

It was observed in the material collected from submerged mosses in unpolluted part of the stream, and was one of the most abundant diatom taxa. It is often recorded from fossil and recent samples in Poland from various type of water environments (e.g. Schumann 1863; Kirchner 1878; Gutwiński 1888; Strzeszewski 1913; Liebetanz 1925; Marciniak and Przybyłowska-Lange 1977).

According to Krammer and Lange-Bertalot (1986) it is frequent, especially in eutrophic waters. It prefers circumneutral (fresh and brackish), $\beta$-mesosaprobous eutrophic waters (Van Dam et al. 1994).

Gomphonema olivaceum (Horn.) Bréb. var. olivaceum Fig. 3: 7-8.

(= Gomphonema olivaceum (Lyngb.) Kütz.)

Ref. Krammer and Lange-Bertalot 1986 (Fig. 165: 1-7); Krammer and Lange-Bertalot 1991 (Fig. 88: 10-13); Lange-Bertalot 1993 (Fig. 80: 9-10, 16-17).

The valves are club-shaped, with narrowed foot-pole, 7.0-42.5 $\mu \mathrm{m}$ long and 3.4-8.6 $\mu \mathrm{m}$ wide. Transapical area is narrow. The transapical striae are radiate in the middle part of the valve, becoming parallel towards the poles, 10.514.0 in $10 \mu \mathrm{m}$. Some observed frustules were shorter than given in the species description.

One of the most abundant diatom species, occurred along the whole stream, more frequent in material collected from filamentous thalli of algae. It is known from various waterbodies of Kraków-Częstochowa Upland (Siemińska 1947; Turoboyski 1962; Skalna 1969; Kubik 1970; Hojda 1971).

It occurs in fresh and brackish waters of wide range of the trophy and electrolyte content (Krammer and LangeBertalot 1986). According to Van Dam et al. (1994) it is alkalibiontic species, occurring exclusively in waters with $\mathrm{pH}$ values exceeding 7 , with fairly high oxygen level, tolerating elevated concentrations of organically bound nitrogen, $\beta$-mesosaprobous, eutraphentic, very rarely noted from exposed habitats.

** Gomphonema parallelistriatum Lange-Bert. and Reichardt Fig. 3: 9-11.

Ref. Krammer and Lange-Bertalot 1991 (Fig. 80: 7-11); Lange-Bertalot 1993 (Fig. 76: 11-16).

Valves lanceolate, slightly heteropolar, 22.0-26.5 $\mu \mathrm{m}$ long and 7.0-7.4 $\mu \mathrm{m}$ wide, with relatively narrow transapical area. Central area pronounced unilateral. The transapical striae parallel, 11.0-12.0 in $10 \mu \mathrm{m}$.

It occurred rarely in the material collected from filamentous thalli of Vaucheria sp. upstream of Kobylany village, where the water was eutrophicated by domestic birds.

This species is so far known from Germany, where it was observed together with Gomphonema micropus from oligosaprobous, and meso- to eutrophic waters with very low electrolyte content (Lange-Bertalot 1993).

Gomphonema parvulum (Kütz.) Rabh. var. parvulum fo. parvulum Fig. 3: 12-15.

Ref. Krammer and Lange-Bertalot 1991 (Fig. 76: 1-4), Reichardt 1999 (33: 22-23, 30-31).

Valves lanceolate, heteropolar 18.5-29.0 $\mu \mathrm{m}$ long and 4.0-6.5 $\mu \mathrm{m}$ wide. Transapical striae parallel to slightly radiate about the central area $9-12$ in $10 \mu \mathrm{m}$. Rarely were 

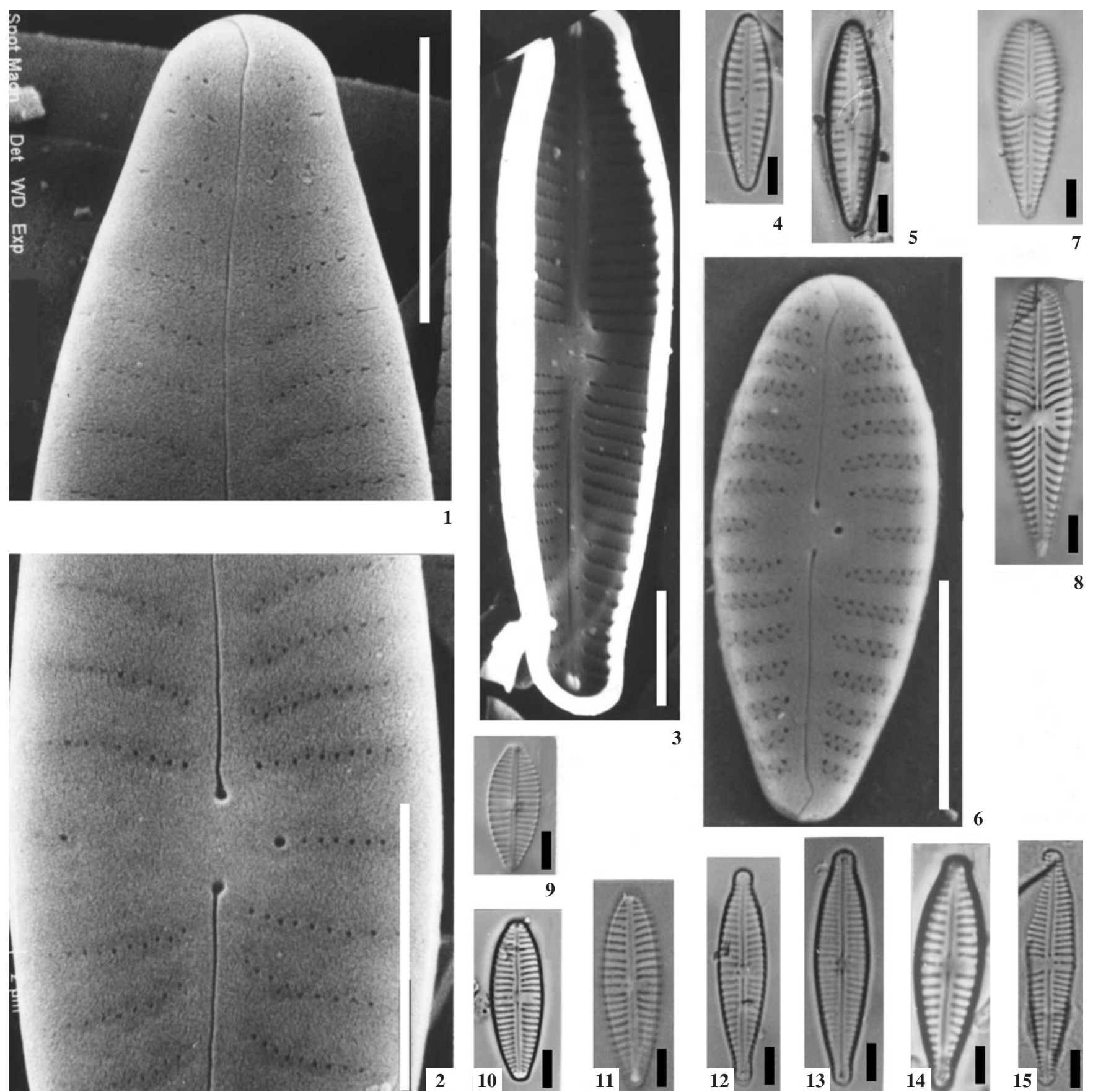

3

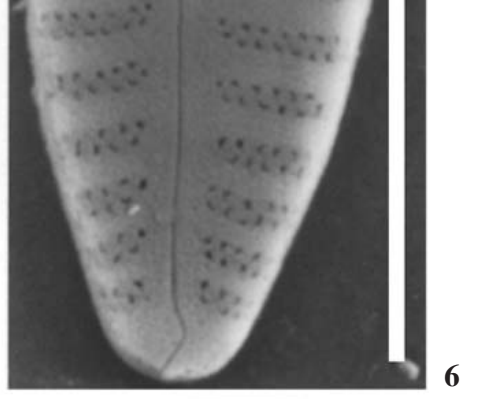

Fig. 3: 1-15: 1-3: Gomphonema micropus Kütz., 4-6: G. minutum (Ag.) Ag. fo. minutum, 7-8: G. olivaceum (Horn.) Bréb. var. olivaceum, 9-11: G. parallelistriatum Lange-Bert. and Reichardt, 12-15: G. parvulum (Kütz.) Rabh. var. parvulum fo. parvulum. Scale bar: 5 um. LM photographs: 4-5, 7-15. SEM photographs: 1-3, 6 .

observed specimens which resembled taxon recorded from oligotrophic Julma Ölkky lake, determined as Gomphonema Julma Ölkky sp. nov. 2 (Lange-Bertalot and Metzeltin 1996) by having slightly triundulate valves and sinuous external raphe fissures (Fig. 3: 15).

It was recorded often from various type of substrate along the whole stream, but the observed populations were moderately abundant.

This species is known from various waterbodies in Kraków-Częstochowa Upland (e.g. Gumiński 1947; Siemińska 1947; Kubik 1970).

This species is widespread and very common in waters of wide range of the trophy (Wołowski 1989; LangeBertalot and Genkal 1999); its mass occurence was recorded in meso- and polytrophic zone (Krammer and Lange-
Bertalot 1991). According to Van Dam et al. (1994) it mainly occurs in fresh and brackish waters at $\mathrm{pH}$ about 7 , and periodically needs elevated concentrations of organically bound nitrogen. It shows good vitality in waters of low oxygen level, $\alpha$-meso- to polysaprobous, eutrophic, often recorded from aerophytic habitats.

Gomphonema pumilum (Grun.) Reichardt and Lange-Bert. Fig. 4: 1-6.

(= Gomphonema intricatum Kütz. var. pumila Grun.).

Ref. Krammer and Lange-Bertalot 1986 (Fig. 164: 7), Krammer and Lange-Bertalot 1991 (Fig. 85: 13-16). Reichardt 1997 (Fig. II: 30-35).

The valves are lanceolate, heteropolar; 13.0-19.8 um long and 4.5-6.0 $\mu \mathrm{m}$ wide. Axial area is narrow, central 

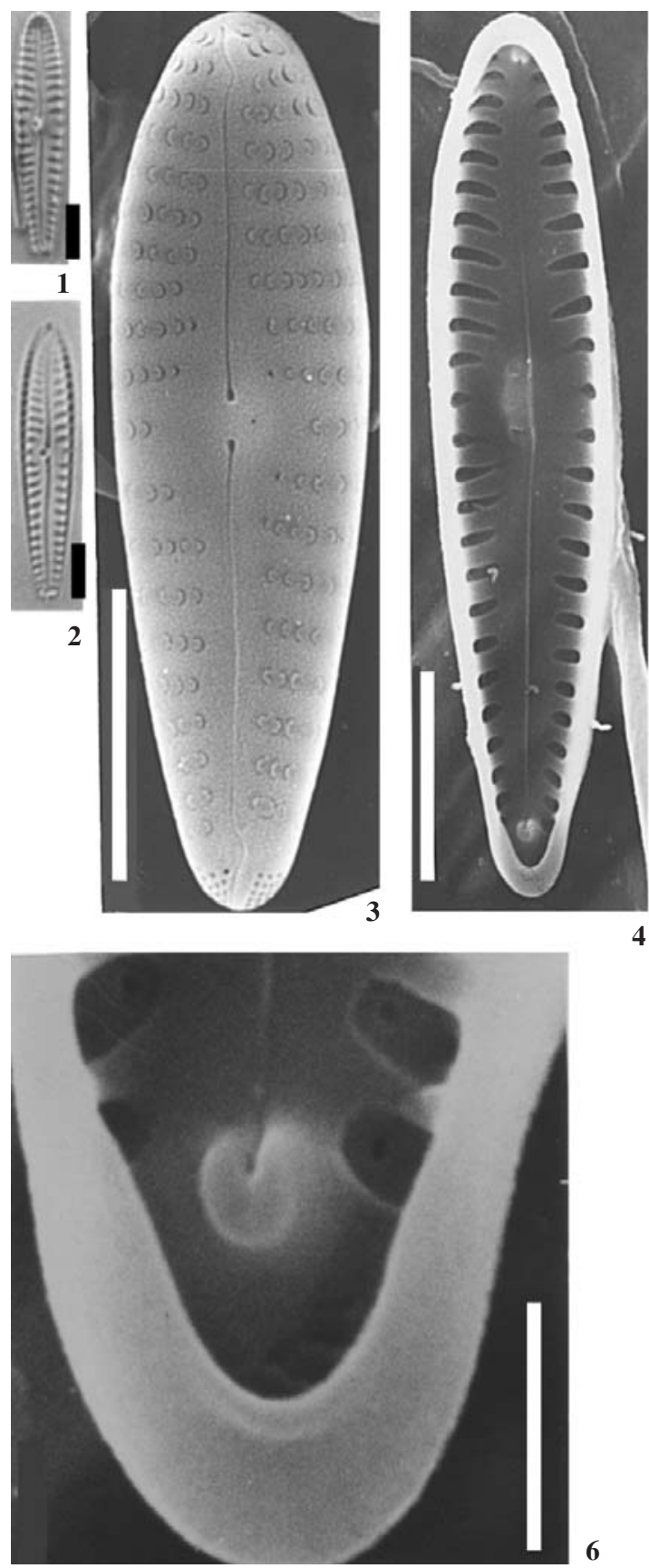

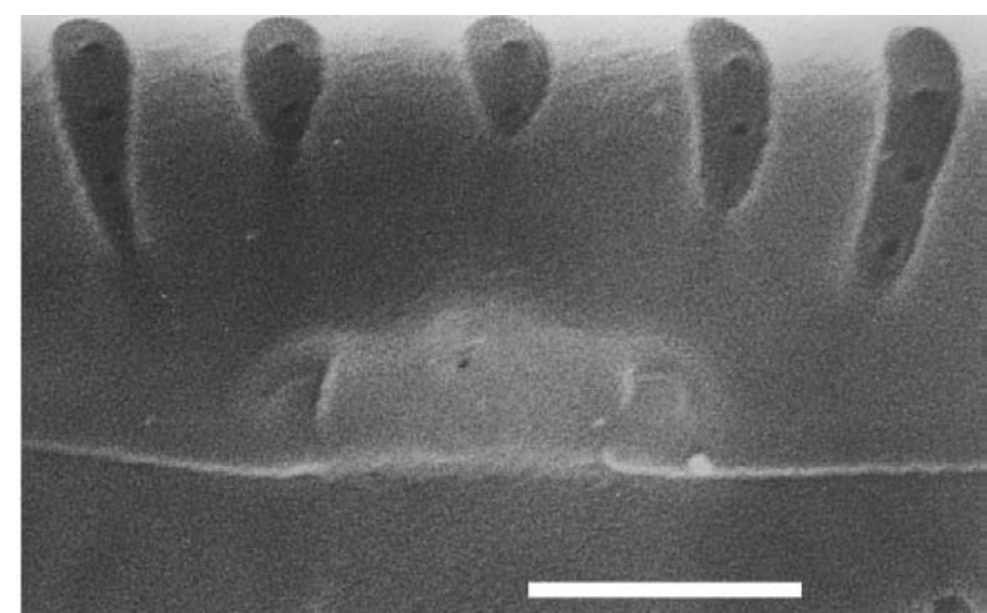

5
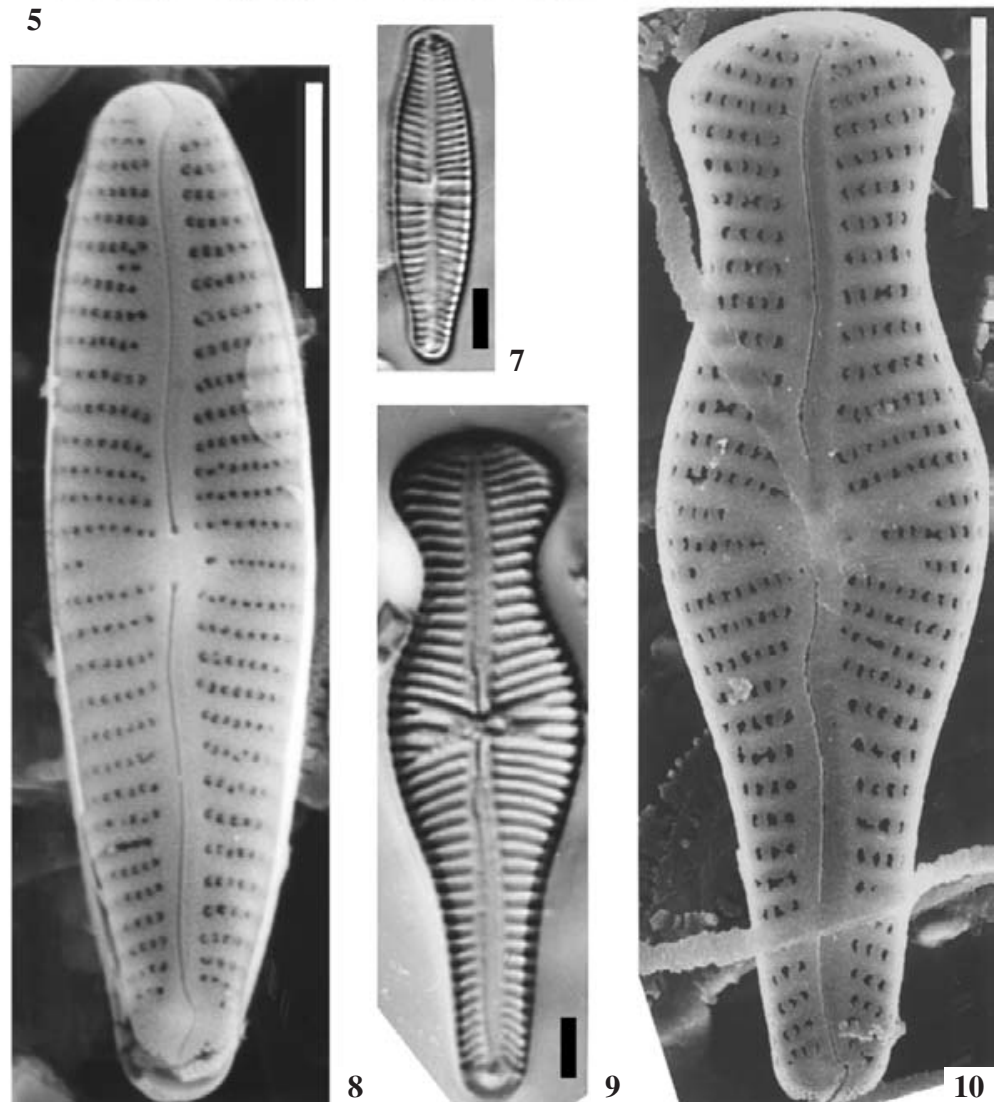

Fig. 4: 1-10: 1-6: G. pumilum (Grun.) Reichardt and Lange-Bert., 7-8: G. sarcophagus Greg., 9-10: G. truncatum Ehr. Scale bars: 5 um (1-4, 7-10); 1 um (5-6). LM photographs: 1-2, 7-9. SEM photographs: 3-6, 8, and 10.

area small. Transapical striae distinct, areolae not resolvable under LM 11.0-12.5 in $10 \mu \mathrm{m}$.

This species was recorded from the mud of unpolluted section of the stream where occurred infrequently.

From the Kraków-Częstochowa Upland so far known only from springs of the Kobylanka stream (Skalna 1969) and Będkówka stream (Kubik 1970). It was also frequently mentioned from other parts of Poland.

Most probably it is widespread (Reichardt 1997), preferring fresh as well as brackish waters of wide range of trophy (Van Dam et al. 1994).

* Gomphonema sarcophagus Greg. Fig. 4: 7-8.

(= Gomphonema angustatum Kütz. var. sarcophagus (Greg.) Grun.).
Ref. Krammer and Lange-Bertalot 1991 (Fig. 75: 1-12), Reichardt 1999 (Fig. 30: 1-30; Fig. 31: 1-6).

Valves lanceolate, heteropolar with slightly capitate apices, 16.0-20.0 $\mu \mathrm{m}$ long and 7.0-7.8 $\mu \mathrm{m}$ wide. Transapical striae consisting of puncta resolvable under LM, 10-12 in $10 \mu \mathrm{m}$.

It was recorded in the material collected from thalli of Vaucheria sp. from unpolluted section of the stream as single specimens.

In Poland reorded so far from the Beskid Makowski and Beskid Żywiecki Mts (Gutwiński 1897) and in Gulf of Gdańsk (Witkowski 1994).

According to Krammer and Lange-Bertalot (1991) it is known from fossil and recent material, where it occurs together with Gomphonema micropus in sediment samples. 
This species occurs in both fresh and brackish waters, alkaliphilous, $\alpha$-mesosaprobous, oligo-mesotraphentic, often recorded in aerophytic habitats (Van Dam et al. 1994).

Gomphonema truncatum Ehr. Fig. 4: 9-10.

(= G. constrictum Ehr.)

Ref. Krammer and Lange-Bertalot 1986 (Fig. 159: 11-18).

The valves are club-shaped, with narrowed foot-pole; 26.0-38.6 $\mu \mathrm{m}$ long and 8.6-10.2 $\mu \mathrm{m}$ wide. The external raphe fissures are slightly sinuous. Central area is small. Transapical striae are parallel, 12 in $10 \mu \mathrm{m}$ with areolae not resolvable under LM.

It occurred in material collected along the whole stream, but was more abundant in unpolluted section on thalli of Vaucheria sp.

Known from various types of waterbodies of Kraków-Częstochowa Upland.

It is a cosmopolitan species, often recorded in streams with water of high electrolyte content up to $\beta$-mesosaprobic zone (Krammer and Lange-Bertalot 1986). According to Van Dam et al. (1994) it occurs in fresh and brackish waters and is determined as alkaliphilous form tolerating very small concentrations of organically bound nitrogen, requiring fairly high oxygen level, $\beta$-mesosaprobous, mesoeutraphentic, occurring sometimes in aerophytic habitats.

\section{DISCUSSION}

In the material studied, populations of Gomphonema micropus were most numerous and inhabited the surface of stones ranging in diameter from 65 to $130 \mathrm{~mm}$. This taxon occurred most frequently in assemblages with other diatom taxa such as Achnanthidium minutissimum (Kütz.) Czarn., Planothidium ellipticum (Cl.) Round and Bukh., P. lanceolatum (Bréb.) Round and Bukh. and Meridion circulare Ag. Other Gomphonema species represented by relatively abundant populations were recorded in the unpolluted section of the stream: G. acuminatum occurred mainly on Lemna minor L., together with Lemnicola hungarica (Grun.) Round and Basson. Gomphonema clavatum Ehr. and G. minutum (Ag.) Ag. occurred in diatom communities on submerged mosses, together with Caloneis bacillum (Grun.) Cl., Cocconeis placentula Ehr., Navicula tripunctata (O. Müll.) Bory and Meridion circulare Ag. On filamentous thalli of Cladophora. sp. in the polluted stream section, the most abundant of all Gompnonema taxa was Gomphonema olivaceum, where it occurred together with Cocconeis pediculus Ehr., Encyonema sp., Fragilaria capucina var. vaucheriae (Kütz.) Lange-Bert., Navicula cryptocephala Kütz., N. gregaria Donk., and N. tripunctata (O. Müll.) Bory. The occurrence of some sensitive species such as Gomphonema acuminatum, G. clavatum, and $G$. truncatum indicates that the stream retains some of its natural character. The favourable environmental conditions necessary for the development of the most abundant species in the studied stream are alkaliphilic, eutraphic and b-mesosaprobous, with a fairly high oxygen level in inhabited waters. These species are all known from streams in calcareous terrain and brackish water environments.

The remaining recorded species usually occurred in small and sparse populations, and might be elements of allochtonic diatom flora or representatives of the group of diatoms most sensitive to anthropogenic changes, which are in regression.

\section{ACKNOWLEDGMENTS}

This work was partly supported by the State Committee for Scientific Research grant no. P204 04404 and 6 P04G 068 21. I am very grateful to doc. dr. hab. Konrad Wołowski for his kind help and critical comments during the preparation of this paper and the anonymous reviewer for very valuable comments on the manuscript. I sincerely thank Michael Jacobs for correcting the English text.

\section{LITERATURE CITED}

FILARSZKY N. 1899. Adatok a Pieninek Moszatvegetatiójehoz. Math. termész. közlem., 27: 1 (723)-8 (800).

GUMIŃSKI S. 1947. Badania sestonu Młynówki pod Krakowem (8.V.1937-25.IV.1938). Acta Soc. Bot. Pol. 18 (2): 155-178. (in Polish)

GUTWIŃSKI R. 1888. Przyczynek do znajomości okrzemek tatrzańskich (Bacillariaceae tatrenses). Spraw. Komis. Fizjogr. 22: 138-150. (in Polish with English summary)

GUTWIŃSKI R. 1893. Materyały do flory glonów Galicyi. Część III. Spraw. Komis. Fizjogr. 28: 104-166. (in Polish)

GUTWIŃSKI R. 1897. Wykaz glonów zebranych w okolicy Wadowic-Makowa. Spraw. Komis. Fizjogr. 32: 97-217. (in Polish)

GUTWIŃSKI R. 1909. Flora algarum montium Tatrensium. Bull. intern. Acad. Sci. Cracovie, Cl. sci. math.-nat. pp. 405-560. (in Latin)

HOJDA K. 1971. Okrzemki górnego biegu potoku Sanka (Wyżyna Krakowsko-Częstochowska). Fragm. Flor. Geobot.17 (3): 445-454. (in Polish)

KIRCHNER O. 1878. Algen. Kryptogamen-Flora von Schlesien, herausgegeben von F. Cohn, Breslau, J.U. Kern's Verlag. 2 (1): 1-284.

KOZŁOWSKI W. 1890. Przyczynek do flory wodorostów okolic Ciechocinka. Pamiętn. Fizjogr. 10: 245-259. (in Polish)

KRAMMER K., LANGE-BERTALOT H. 1986. Bacillariophyceae. 1. Naviculaceae. In: Süßwasserflora von Mitteleuropa. 2 (1), H. Ettl, J. Gerloff, H. Heyning, D. Mollenhauer (eds). pp. 1-876. Gustav Fischer Verlag, Stuttgart-New York.

KRAMMER K., LANGE-BERTALOT H. 1991. Bacillariophyceae. 4. Achnanthaceae, Kritische Ergänzungen zu Navicula (Lineolatae) und Gomphonema, Gesamtliteraturverzeichnis. In: Süßwasserflora von Mitteleuropa. 2 (4), H. Ettl, G. Gärtner, J. Gerloff, H. Heyning, D. Mollenhauer (eds). pp. 1-437. Gustaw Fischer Verlag, Stuttgart-Jena.

KRAMMER K., LANGE-BERTALOT H. 2000. Bacillariophyceae. 5. English and French translation of the keys. In: Süßwasserflora von Mitteleuropa. 2 (5), B. Büdel, G. Gärtner, L. Krienitz, G.M. Lokhorst (eds), pp. 1-311. Spectrum Akademischer Verlag Heidelberg, Berlin.

KUBIK B. 1970. Okrzemki trzech źródeł potoku Będkówka (Wyżyna Krakowsko-Częstochowska). Fragm. Flor. Geobot. 16 (4): 549-561. (in Polish with English summary)

LANGE-BERTALOT H. 1993. 85 new taxa and much more than 100 taxonomic clarifications supplementary to Süßwasserflora von Mitteleuropa. 2 (1-4): 1-454. Bibliotheca Diatomologica 27. J. Cramer, Berlin-Stuttgart.

LANGE-BERTALOT H. 1997. As a practical diatomist, how does one deal with the flood of new names? Diatom 13: 9-12.

LANGE-BERTALOT H. 1999. A first „Red List” of endangered taxa in the diatom flora of Germany and of Central Europe interpretation and comparison. In: Proc. $14^{\text {th }}$ Diatom Sympo- 
sium. In: S. Mayama, M. Idei, I. Kozumi (eds), pp: 345-351. Koeltz Scientific Books, Koenigstein.

LANGE-BERTALOT H., METZELTIN D. 1996. OligotrophieIndikatoren. 800 Taxa in drei ökologisch diversen Seen-Typen. In: Iconographia Diatomologica. Annotated Diatom Micrographs 2. pp. 1-390. H. Lange-Bertalot (ed.). Koeltz Scientific Books, Koenigstein.

LANGE-BERTALOT H., GENKAL S. 1999. Diatoms from Siberia I. In: Iconographia Diatomologica. Annotated Diatom Micrographs. 6: 1-265. H. Lange-Bertalot (ed.). Koeltz Scientific Books, A.R.G. Gantner Verlag K.G.

LIEBETANZ B. 1925. Hydrobiologische Studien an Kujawischen Brackwässern. Bull. intern. Acad. Polon. Sci. Lettres., Cl. Sci. math. nat., Sér. B. sci. nat. pp. 1-116.

MARCINIAK B., PRZYBYŁOWSKA-LANGE W. 1977. Flora okrzemek plejstocenu i holocenu. In: Budowa geologiczna Polski, tom II, Katalog skamieniałości, część 3b, Kenozoik, czwartorzęd, Instytut Geologiczny. Warszawa, Wydawnictwa geologiczne: 123-146. (in Polish)

MROZINSSKA T. 1989. Algae of the Pieniny National Park (a guide). 19th International Phytogeographic Excursion 1989, July 7-26. „Flora and vegetation of Poland. Changes, Management and Conservation": 1928-1988. Kraków: 1-20.

REICHARDT E. 1997. Taxonomische Revision des Artenkomplexes um Gomphonema pumilum (Bacillariophyceae). Nova Hedwigia 65: 99-129.

REICHARDT E. 1999. Taxonomy. Zur Revision der Gattung Gomphonema. Die Arten um G. affine/insigne, G. angustatum/micropus, G. acuminatum sowie gomphonemoide Diatomeen aus dem Oberoligozän in Böhmen. In: Iconographia Diatomologica. 8: 1-203. In: Annotated Diatom Micrographs, H. Lange-Bertalot (ed.). Koeltz Scientific Books, A.R.G. Gantner Verlag K.G.

ROUND F.E., CRAWFORD R.M., MANN D.G. 1990. The diatoms, biology and morphology of the genera. Cambridge, Univ. Press pp. 1-747.

SCHUMANN J. 1863. Preussische Diatomeen. Schr. Phys.-Ökon. Ges. Königsberg, 3 (1862): 166-190.
SCHUMANN J. 1867. Die Diatomeen der Hohen Tatra. Verh. K. K. Zool.-Bot. Ges. Wien, 17: 1-102.

SIEMIŃSKA J. 1947. Zimowa flora okrzemek w stawach Rybackiej Stacji Doświadczalnej UJ w Mydlnikach koło Krakowa. Arch. hydrobiol. rybactwa. 13: 181-220. (in Polish with English summary)

SKALNA E. 1969. Okrzemki trzech źródeł potoku Kobylanka (Wyżyna Krakowsko-Częstochowska). Fragm. Flor. Geobot. 15 (2): 245-254. (in Polish with English summary)

SKALSKA T., KACZMARCZYK D. 1980. Peryfitonowe okrzemki trzech stawów śródleśnych w Strzybnicy (GOP). Acta Biol., 9, Prace nauk. Uniw. Śląsk., 375: 237-252. (in Polish with English summary)

STRZESZEWSKI B. 1913. Przyczynek do znajomości flory wód siarczanych okolic Krakowa. [Beitrag zur Kenntnis der Schwefelflora in der Umgebung von Krakau]. Bull. intern. Acad. Sci. Cracovie, Cl. Sci. Math. Nat., Sér. B. Sci. Nat. 6: 309-334. (in Polish)

TUROBOYSKI L. 1962. Wstępne badania nad występowaniem okrzemek w Wiśle w Krakowie. Ekol. Pol., Ser. A. 10 (9): 273-284. (in Polish)

VAN DAM H., MARTENS A., SINKELDAM J. 1994. A coded checklist and ecological indicator values of freshwater diatoms from the Netherlands. Netherlands J. Aquatic Ecol. 28: 117-133 .

WITKOWSKI A. 1994. Recent and fossil diatom flora of the Gulf of Gdańsk, Southern Baltic Sea. 1-313. Bibliotheca Diatomologica 28. J. Cramer, Berlin-Stuttgart.

WOJTAL A. 2001. Zbiorowiska okrzemek występujących w potoku Kobylanka na Wyżynie Krakowsko-Częstochowskiej. (The diatom communities from Kobylanka stream on the Kraków-Częstochwa Upland). Ph. D. thesis - 1-193 pp. Instytut Botaniki, Polska Akademia Nauk, Kraków.

WOŁOWSKI K. 1989. The algae occurring in an uncovered trickling filter of a sewage treatment plant in Cracow. Algol. studies 55, Arch. Hydrobiol. Suppl. 82 (2): 207-239.

\author{
OKRZEMKI Z RODZAJU GOMPHONEMA EHR. (BACILLARIOPHYCEAE) \\ W KRASOWYM POTOKU NA WYŻYNIE KRAKOWSKO-CZECTOCHOWSKIEJ
}

\title{
STRESZCZENIE
}

Badania nad występowaniem okrzemek w źródłach i potoku Kobylanka (około 30 km na północny zachód od Krakowa) prowadzono w latach 1993-2001. Spośród odnotowanych na tym niewielkim terenie 272 taksonów okrzemek 13 należało do rodzaju Gomphonema. Gatunki należące do rodzaju Gomphonema należą do grupy najliczniej występujących okrzemek poroślowych w badanym materiale. W pracy zamieszczono dane o ich występowaniu na terenie Wyżyny Krakowsko-Częstochowskiej i w Polsce, preferencjach siedliskowych a także dokumentację fotograficzną wykonaną przy użyciu mikroskopu świetlnego i elektronowego skaningowego.

Występowanie w badanym materiale gatunków alkalofilnych, oligosaprobowych, mezotroficznych (Gomphonema acuminatum, G. clavatum i G. truncatum świadczy o przynajmniej częściowym zachowaniu naturalnego charakteru badanego potoku i źródeł. Do tej grupy należą również - rzadko podawane z Europy i nowe dla flory Polski Gomphonema brebissonii, G. lagerheimii oraz G. parallelistriatum.

SŁOWA KLUCZOWE: Bacillariophyceae, Gomphonema, taksonomia, ekologia, potok, rozmieszczenie, Wyżyna Krakowsko-Częstochowska. 